\title{
Bioética e zika vírus na imprensa brasileira: reflexões psicossociais
}

\author{
Bioethics and zika virus in the Brazilian press: psychosocial reflections
}

\author{
Lassana Danfá ${ }^{1}$ \\ Edclécia Reino Carneiro de Morais²
}

\begin{abstract}
RESUMO: A epidemia de Zika vírus tem gerado debates nos mais diversos espaços sociais, devido ao clima de incerteza sobre suas causas e consequências. A sociedade investe expectativas nos poderes públicos e comunidade científica para o oferecimento de soluções para a epidemia. Para a psicologia social, este contexto controverso constitui um campo fértil de reflexão, elaboração e circulação de representações sociais, suscitadas pela interpenetração entre os discursos científicos e os discursos de senso comum. Neste artigo, propomos estudar as reflexões bioéticas sobre zika vírus enquanto fenômeno socialmente construído. Os dados foram coletados entre janeiro de 2015 e agosto de 2016. Foram encontradas 114 matérias (revista Veja=98 e revista Carta Capital=16), que continham nos títulos zika e zika virus. Os textos foram processados através do software iramuteq,que proporcionou a análise de classificação hierarquica descendente e análise fatorial de correspondência. Apresentamos dados comparativos entre duas revistas com posicionamentos politico-ideologicos distintos: Veja e Carta Capital. Esperamos contribuir para o debate sobre processo de ancoragem na construção de objetos sociais via comunicação social. Os resultados obtidos na Carta Capital traz dimensões macrossociais sobre a zika, debruçando em questões ligadas às políticas públicas de saúde, determinantes sociais da doença e iniquidades sociais. A revista Veja aponta para aspectos microssociais, enfatizando uma dimensão intrapessoal. As diferenças ideológicas foram notáveis no posicionamento das duas revistas. De um lado, uma ideologia progressista, que pode estar relacionado com a ênfase na crítica das políticas públicas, de outro, próximo de uma ideologia neoliberal, colocando relevo no indivíduo como entidade privada.
\end{abstract}

Palavras-chave: zika; vírus ; bioética; revista; representações sociais.

ABSTRACT: The zika vírus epidemy has generated discussions in many social spaces, due to the uncertain climate about its causes and consequences. The society invests expectations in the public authorities and scientific authorities for the solutions of the epidemic situation.This controversial context constitutes a fertile field of reflection, elaboration and circulation of social representations raised by the interpenetration between scientific and common-sense discourses. We aim to investigate the circulation and polarization of bioethical reflexions about zika virus on brazilian media in the view of social representations. The data were collected between 2015/ january and 2016/ august. 114 press articles were found (Veja Magazine=98 e Carta Capital magazine=16) that contained "'zika" and "zika virus" on their titles. The texts were proccessed by the iramuteq software, that provided the hierarchical classification analysis and the factorial matching analysis. We present comparative data between two periodical with distinct ideological political positions. We await to contribute for the debate on the anchorage in the construction of social objects via social communication. The results obtained on Carta Capital show macrossocial dimentions about zika, leaning on questions linked to public health politics, social determinants of disease and social inequities.Veja magazine points to microssocial aspects, emphasizing an intrapessoal dimension. The ideological differences were notable on positioning of the two reviews.In one hand, the progressive ideology, that may be related to the critical emphasis of

\footnotetext{
${ }^{1}$ Psicólogo, mestre e doutorando em Psicologia pelo programa de Pós-Graduação em Psicologia da Universidade Federal de Pernambuco. Integrante do Laboratório de Interação Social Humana (LabINT) - Recife, PE, Brasil. E-mail: delassanadanfa@hotmail.com.

2 Psicóloga, mestra em Psicologia e doutora em Psicologia pelo Programa de Pós-Graduação em Psicologia da Universidade Federal de Pernambuco (UFPE). Integrante do Laboratório de Interação Social Humana (LabINT) - Recife, PE, Brasil.
} 
public policies; on the other hand near a neoliberal ideology, highlighting the individual as a private entity.

Keywords: zika; virus; bioethics; magazine; social representations.

\section{Introdução}

Apesar dos grandes avanços da industrialização, vivemos uma sociedade de risco e de grandes catástrofes (Ungar, 2001; Beck, 2010), uma vez que os grandes males e/ou doenças emergentes não conseguiram ser evitados, por vezes, devido à negligência dos atores sociais capazes de intervir.

O surgimento da epidemia de zika no Brasil, em 2016, trouxe à tona uma conjuntura surpreendente nas políticas da vida. Segundo Rose (2013, p. 79), "a nossa percepção do que é e do que não é vida, vivente ou vivo, é com frequência, exatamente o que está em jogo na política atual". Nesse sentido, em tempos de crise potencial, como nos casos das epidemias, o reconhecimento e a valorização de vidas é necessário e fundamental para que hajam políticas públicas eficazes para a população mais vulnerável.

A transmissão vertical do vírus, ou seja, a possibilidade de transmissão em gestação da mãe para o feto, suscita não apenas debate sobre a biopolítica das populações de risco, que carecem de condições habitacionais dignas, mas também a incerteza da ciência e o cuidado que se estabelece com os corpos, principalmente o corpo feminino. $\mathrm{O}$ seu advento fez eclodir, mais uma vez, o debate ético em torno de acesso à informação, e, por conseguinte a liberdade de escolha concernente à saúde reprodutiva das mulheres (Diniz \& Brito 2016).

O surgimento do zika, de acordo com os cientistas ocidentais, foi associado à floresta Zika na Uganda em 1947. Apesar da sua associação com Uganda, África, a cepa do vírus encontrada no Brasil tem $99 \%$ de semelhança com o da Polinésia francesa, o que refuta a hipótese de importação do vírus durante a Copa do Mundo de 2014. Aliás, o mosquito ocasionador do zika nunca deixou o território brasileiro, ou seja, o mosquito Aedes Aegypti, causador de arboviroses (zika, dengue, febre amarela) convive com os brasileiros desde o século passado (Diniz \& Brito, 2016).

O vírus Zika foi notificado em mais de 61 países, maioria nas Américas. A primeira notificação no Brasil ocorreu em maio de 2015, em Natal, Rio Grande do Norte. Em 11 de novembro de 2015 houve uma declaração de Emergência Nacional em Saúde Pública pelo Ministério da Saúde após notificação do crescimento de casos de microcefalia em bebês nos estados da Paraíba, Pernambuco e Rio Grande do Norte. O boletim de 27 de julho de 2016 informou 1.764 casos de microcefalia por zika confirmados no país e mais 3.062 em investigação. Dentre estes, o Estado de Pernambuco se destacou com 376 casos confirmados, seguido do Estado da Paraíba com 155 (Ministério da saúde, 2016).

A epidemia de Zika vírus tem gerado debates que implicam os poderes públicos, a sociedade civil, a comunidade acadêmica, entre outros. Diante do aumento dos casos de microcefalia em bebês recém-nascidos, especialmente nos estados de Pernambuco, da Paraíba e do Rio Grande do Norte os pesquisadores têm procurado elucidar as possíveis relações entre os casos de microcefalia e a infecção por zika vírus. O medo de que a epidemia se alastre pela América Latina fez com que a Organização Mundial de Saúde aconselhasse a despenalização do aborto nos países onde o aborto é crime. Foi um dos raros momentos na 
cena pública brasileira no qual a discussão sobre a despenalização do aborto ganhou manchetes e visibilidade nas comunicações midiáticas de massa.

Nesse sentido, percebe-se o lugar de destaque que a epidemia de microcefalia alcançou na agenda jornalística do país entre o final de 2015 e o ano de 2016. A ascensão desse conteúdo a um lugar de interesse na cena pública chama atenção tanto em função das hipóteses explicativas do tipo causal sobre o vírus da zika (origens, causas) e a doença (uso de pesticidas), quanto para preocupações sobre a situação de precariedade das famílias acometidas por microcefalia (abandono de crianças, abandono de famílias pelos genitores etc.), ou rumores que aparecem no senso comum sobre uma ligação com vacinas.

O crescimento de difusão de informações sobre o tema, associado a uma mobilização social para engajamento da população, ativa um terreno fértil para ascensão de valores e variação de posicionamentos sociais sobre o vírus, a doença e suas repercussões sociopolíticas. Desse modo, a epidemia associada ao Zika vírus ganha ênfase entre os conflitos bioéticos mais atuais no Brasil. A bioética tem se tornado um campo de saber propício para reflexão e regulação de questões polêmicas e socialmente sensíveis, e se destaca principalmente na mediação de conflitos sociais relacionados à saúde.

O termo bioética surge em 1971, nos Estados Unidos, na obra do médico cancerologista Potter (Bateman-Novaes, 1998; Diniz \& Guilhem, 2002). A bioética desenvolve-se como um movimento intelectual de estudo da ética biomédica e posteriormente, como um processo de institucionalização das práticas de experimentação com seres humanos. Desde os primórdios do seu desenvolvimento, os médicos ocuparam um lugar privilegiado enquanto autoridade moral nas discussões e na institucionalização da bioética como disciplina, nos Estados Unidos, mas também na França e na Europa de forma geral. De acordo com Galloux (2002) a instituição da bioética na Europa teve como impacto limitar o debate público, suprimir a expressão de uma diversidade de opiniões e a imposição de uma ética de establishment médico-científico.

No Brasil, a bioética nasce como campo de reflexão nos anos 90 e fica, durante um longo período, circunscrita à questão da institucionalização dos comitês de ética em pesquisa nas universidades, nos hospitais e nos centros de pesquisa (Diniz, Guilhem, \& Garrafa, 1999). Desenvolveu-se timidamente ligada a uma dimensão pragmática e política visando à redução da pobreza e da desigualdade social, trata-se de uma bioética confrontada aos problemas gerados pela exclusão e injustiça social no campo da saúde (Schramm, 2002).

O surgimento da bioética como campo disciplinar gera questões que não concernem apenas pesquisadores e médicos, mas interrogam as sociedades sobre seus valores, suas crenças e suas normas (Bateman-Novaes, 1997; Le Coz, 2009). Segundo Simone Bateman (1998, p.7), a bioética é um objeto multidimensional cuja unidade pode ser estabelecida através de estudos dos conflitos "Onde se confrontam diferentes visões do mundo, organizadas em sistema de ação em torno de uma regulação normativa". Para Débora Diniz (2008), a bioética é um campo interdisciplinar de reflexões sobre conflitos morais em saúde. Neste trabalho, especificamente, temos interesse em interrogar que conflitos morais aparecem (ou não) ligados ao zika vírus na cena pública brasileira. Em outras palavras, buscamos refletir, à luz da Teoria das Representações Sociais (TRS), sobre como a comunicação social participa da construção do risco no contexto da epidemia de zika na qualidade de objeto social - interrogando: de que risco se fala sobre zika? quem é revestido, na arena pública, de autoridade moral para falar? 
As diferentes categorizações que um objeto pode sofrer remetem à variedade nos potenciais sistemas de ancoragens de uma determinada sociedade, ou seja, a "engajamentos anteriores em direção de um sistema conceitual, de uma ideologia, de uma ontologia e de um ponto de vista" (Moscovici \& Hewstone, 2005). Podemos identificar, com relação aos conteúdos que constituem o campo representacional da AIDS e do Ebola, por exemplo, a metáfora da campanha militar, segundo a qual a população trava uma guerra contra os vírus (Danfá, 2016). Acreditamos que esta ideia de combate seja acentuada e reatualizada no âmbito da epidemia de zika.

O segundo aspecto que merece aprofundamento teórico-metodológico, por ter articulações com a ancoragem, diz respeito às relações entre ideologia e imprensa. $O$ trabalho pioneiro de Moscovici (1961) nos mostrou que o clima ideológico e a posição ideológica dos jornais estudados produziram diferentes formas de falar de psicanálise (difusão, propagação e propaganda) cada uma delas resultando em produtos distintos (formação de opiniões, formação de atitudes e formação de estereótipos). São raros os trabalhos no Brasil que colocam em perspectiva veículos explicitamente distintos em termos de posições políticoideológicas. Ainda de acordo com Joffe (2005), no contexto da saúde, os meios de comunicação não reproduzem artigos científicos, mas são responsáveis por gerar um clima ideológico. A autora mostra isso em relação, por exemplo, ao vírus ebola e à epidemia de gripe aviária - que, representadas na imprensa britânica, suscitam preconceito em relação aos africanos, para o caso da primeira, mas não em relação aos chineses, no caso da segunda.

No caso da AIDS, os estudos de Markova e Wilkie (1987) sobre a mídia britânica, Herzlich e Pierret (2005) sobre a mídia francesa e Spink, Medrado, Menegon, Lyra e Lima (2001) no Brasil, demonstram a capacidade da mídia em construir a AIDS como um fenômeno social, transformando-a em uma doença do cataclismo coletivo, capaz de gerar pânico e orientar as relações e práticas sociais. A AIDS, diferentemente do zika e ebola, traz além da ansiedade social generalizada o pânico moral, remetendo ao discurso em torno da segurança e criação dos "demônios sociais" (Ungar, 2001). Ou seja, além do discurso que apela à segurança social, a mídia constrói a noção do risco, associando-o imaginariamente e preconceituosamente aos grupos tidos como moralmente "desviantes".

Neste sentido, encontramos elementos identitários no cerne da questão da elaboração de representações sociais no campo da saúde, já explorados pelos estudos de Joffe (para não citar outros autores). No caso do zika vírus, pudemos observar, em redes sociais como o twitter (meios informais de comunicação) o jogo de culpabilização dos nordestinos, ativando tal dimensão identitária.

O surgimento do zika está ligado diretamente à construção de uma realidade social caracterizada pela iniquidade social, o que pode favorecer a produção social de doenças e o agravamento das desigualdades sociais. Surge igualmente num contexto de polarização no seio da sociedade brasileira, o que explica as atitudes como a sua associação com os nordestinos. Este processo de atribuição de causalidades, mobilização de emoções, medo, pânico, ansiedade social generalizada, clima de estupor e projeção no exogrupo com intuito de proteger identidade e acalmar os ânimos do endogrupo, são processos psicossociais que o advento do zika reatualiza (Herzlich \& Pierret, 1988; Joffe, 2005; Ungar, 2001).

Em recente estudo sobre ebola, Danfá (2016) demonstrou o modo como a mídia transformou em um risco "real" uma doença solitariamente atrelada ao continente africano, gerando angústia, ansiedade e sensação da perda do controle, da ameaça que este "mal" 
causa nas pessoas que vivem nas fronteiras além África. Diferentemente do ebola, a cepa/linhagem do vírus da zika presente no Brasil carrega semelhanças não com África, e sim, com o sul da Ásia, mais concretamente na polinésia francesa. Sendo assim, acreditamos que a elaboração do risco através da mídia brasileira passa a ser o modo como uma doença desconhecida e presente no Brasil gera pânico nacional, em especial nas mulheres. Este último devido à associação da "síndrome congênita do Zika" (Diniz, 2016) com a microcefalia nos bebés recém-nascidos, abrindo espaço para debate no campo da bioética, principalmente sobre o aborto.

Pode-se dizer que o risco associado ao zika se intensificou com as hipóteses científicas levantadas nos EUA e na França sobre a possibilidade da transmissão sexual do zika. Este tipo de risco está relacionado com a proibição do contato (Moscovici, 2011), neste caso, não com pessoas tidas como impuras ou sujas como nos casos da AIDS e do ebola, mas sim com o perigo de contato relacionado ao mosquito aedes aegypti. Observa-se assim uma progressiva interação entre pesquisadores e opinião pública - "a sociedade do risco é também a sociedade da ciência, da mídia e da informação" (Beck, 2001 p. 84). "O vírus Zika, assim como o HIV e a dengue foram um dia, é um típico caso de vírus emergente, que surge em locais onde anteriormente não existia. Sua introdução e seus impactos no país são uma boa oportunidade para observar a relação entre a mídia e a saúde" (Aguiar \& Araújo, 2016 p.3). As autoras analisaram nove jornais das cinco regiões do Brasil quanto à cobertura do zika e da microcefalia. Como principais resultados mostram que a imprensa deu especial destaque à epidemia após o Ministério da Saúde decretar estado de emergência em saúde pública no mês de novembro de 2015. Ao analisar as capas dos referidos jornais, Aguiar e Araújo (2016) observaram que o jornal Correio da Paraíba utilizava as palavras "medo" e "risco" com maior frequência (8 vezes em 30 capas) contra 4 vezes em 39 capas para o Jornal de Commercio.

O exemplo da AIDS na imprensa (Herzlich \& Pierret, 1988; Markova \& Wilkie, 1987) ilustra como o olhar proposto pelo paradigma teórico das representações sociais permitiu mostrar que a elaboração de representações a propósito deste objeto e de sua emergência como "questão da sociedade" refletia tensões, polarizações de relações sociais e pontos focais de preocupações sob um plano científico, econômico, político, cultural e moral. Danfá (2016), também embasado na teoria das representações sociais, mostra como a imprensa brasileira construiu o ebola como problema social de forma racista. Segundo o autor, os veículos estudados (Folha de São Paulo; Revista Veja) lançam um olhar valorativo em relação ao "outro africano" ligando-o à sujeira, impureza, incivilidade, descontrole.

No quadro desse artigo, objetivamos estudar o fenômeno social zika enquanto objeto socialmente construído, que suscita controvérsia e debate bioético, potencializados pelo impacto da hipotética associação do vírus com microcefalia nas mulheres grávidas. Com efeito, em função de fatores conjunturais, situacionais ou temporais, certos elementos ligados à questão da epidemia zika podem gerar debates públicos mais intensos, enquanto que outros escapam às polêmicas. Em outras palavras, poderemos identificar um fenômeno de focalização (Moscovici, 1961). Trata-se de uma abordagem que enfatiza a interdependência entre processos e conteúdos representacionais, de forma a dar conta do enraizamento de representações sociais numa dada cultura (ancoragem). Na realização desta pesquisa, procurou-se estudar as representações sociais sob vários níveis e aspectos conceituais, entre eles: a particularidade social do objeto, a orientação processos/conteúdos e a dimensão simbólica ligada à atividade representativa. 


\section{Método}

\section{Procedimentos de coleta de dados}

Foi realizado um levantamento na interface online de duas revistas nacionais com posicionamentos político-ideológicos explicitamente distintos: Veja e Carta Capital. Foram utilizados como descritores os termos: Zika e Zika Vírus. O recorte temporal do levantamento foi de janeiro de 2015 a agosto de 2016, considerando o interesse em analisar as matérias publicadas no fervor dos debates sobre o Zika vírus, o surgimento da epidemia e a construção da atmosfera do risco.

Após o levantamento, foram selecionadas 114 matérias jornalísticas, que continham os descritores no título ou subtítulo da matéria, das Revistas Veja ( $N=98)$ e Revista Carta Capital $(N=16)$.

\section{Procedimentos de análise de dados}

As matérias foram inseridas em um documento de texto para processamento no software Iramuteq (Interface de R pour les Analyses Multidimensionnelles de Textes et de Questionnaires) concebido por Ratinaud e que permite a análise textual dos textos gerados na entrevista ou nos arquivos do domínio público (Justo \& Camargo, 2013). O software oportuniza a análise de classificação hierárquica descendente (CHD) ou método Reinert, que possibilita a identificação de mundos léxicos, isto é, as palavras significativamente conectadas entre si (Kalampalikis \& Moscovici, 2005). Possibilita também a análise de correspondência (AFC), uma técnica que possibilita a constatação de agrupamento de polos semânticos convergentes e divergentes (Nascimento \& Menandro, 2006). Para entrada no software, foi utilizada, por convenção do software, a seguinte linha de comando com asteriscos para cada matéria: *****Mat_ ${ }^{*}$ Rev_ (Veja ou Carta Capital), *Fonte, isto é, a procedência ou originalidade da notícia publicada (própria revista; fonte externa nacional ou fonte externa internacional) *Período_(2015 ou 2016). Agrupamos as classes, levando em conta as percentagens das Unidades de Contextos Elementares (UCEs), que são definidas através dos critérios da volumosidade do texto e as respectivas pontuações (Menandro \& Nascimento, 2006).

\section{Resultados e discussão}

\section{Classificação hierárquica descendente}

Os resultados obtidos através da classificação hierárquica (CHD) fizeram emergir dois subcorpora e 4 classes ou mundos lexicais, apresentados no dendrograma da Figura 1 . 0 primeiro, denominamos de discurso de autoridade política (nacional e internacional), constituído pelas classes 1 , nomeada de jogos olímpicos, que contém 21,3\% de UCEs e a classe 2, denominada Ministério da Saúde e ações de combate, que contém 27,9\% de UCEs. 0 segundo subcorpus, que chamamos de discurso de autoridade científica (origens, causas $e$ consequências), é constituída pelas classes 3 , denominada manifestações e origens do Zika, 
contendo $14,1 \%$ de UCEs e a classe 4 , nomeada de consequências de zika, que contém $36,6 \%$ de UCEs.

\section{Zika $(49,67 \%)$}

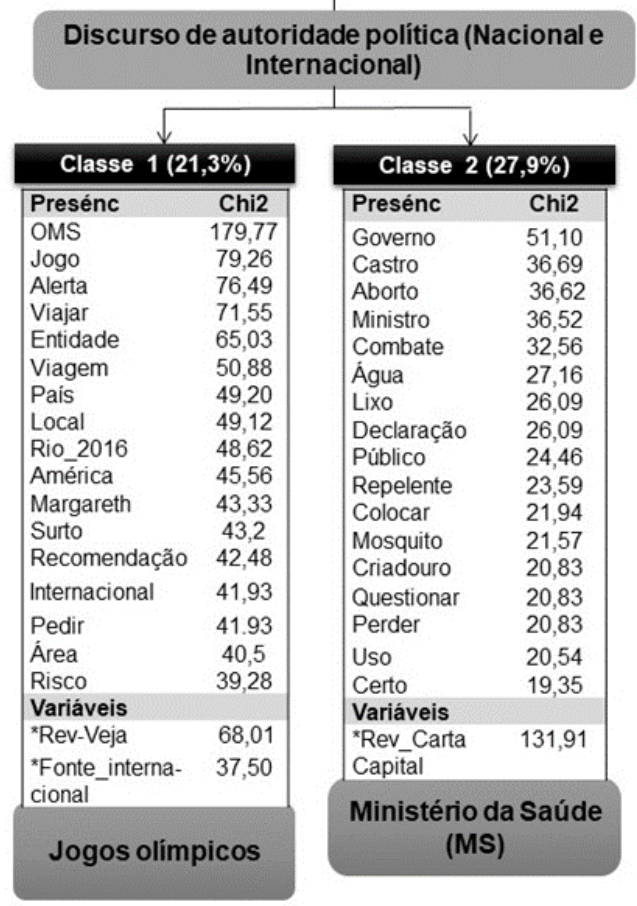

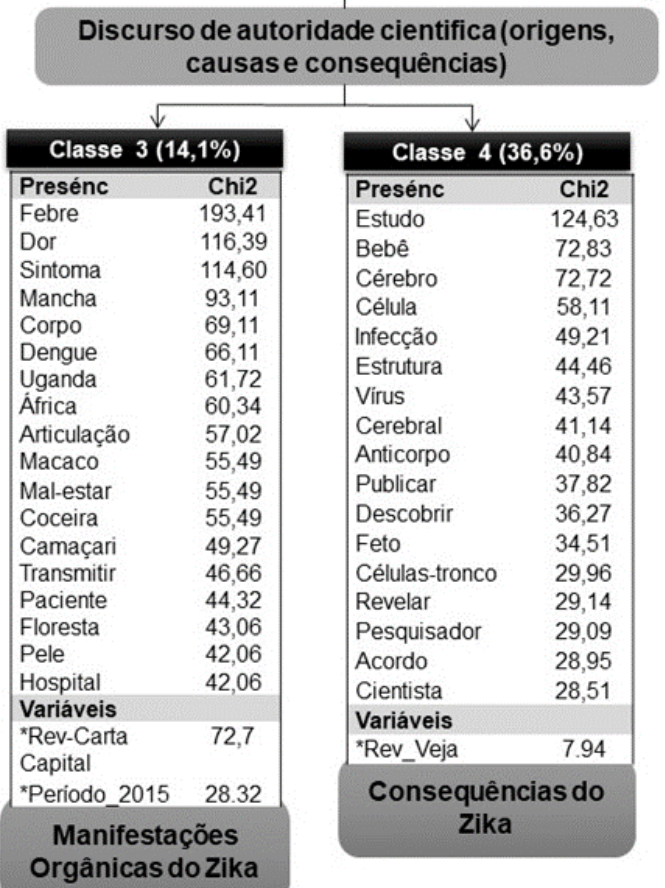

Figura 1 - Dendrograma: notícias sobre Zika

Os subcorpora serão apresentados a seguir, da esquerda para a direita. Iniciando com: discurso de autoridade política (nacional e internacional), dividida em duas classes: a classe 1 - jogos olímpicos e a classe 2-Ministério da Saúde e ações de combate.

$\mathrm{Na}$ classe 1, as palavras mais representativas são: oms, países, Margareth Chan, entidade, alertar, jogos, organização, atletas, diretora geral. E as palavras significativamente ausentes foram: estudo, bebê, cérebro. As variáveis associadas a esta classe foram: Rev_VE (revista veja) e *Font_Ex2, modalidade atribuída a matérias cuja fonte original da publicação foi a mídia internacional. Esta classe traz um debate acerca das repercussões e consequências do aparecimento do zika vírus bem como seus efeitos na organização e planejamento dos jogos olímpicos no Brasil. Destacam-se conteúdos sobre preocupações de ordem coletiva acerca da recepção de estrangeiros no país, controle mundial sobre a transmissão e circulação do vírus para outros países em função da concentração de nacionalidades para os jogos no Rio de Janeiro. Segue o trecho que representa esta classe

O Comitê Olímpico Internacional (COI) divulga recomendações contra o vírus zika. A comissão médica do COI enviou memorando aos comitês e federações com alertas quanto a métodos de prevenção e repassou a sugestão de que mulheres grávidas não devem viajar a zonas com casos reportados da doença (*****Mat_78*Rev_Veja *Font_RE *Periodo_2016)

Essa atmosfera de grande ansiedade social generalizada, clima de estupor e possibilidades de danos futuros que zika pode ocasionar, fez com que vários países 
decretassem alertas aos respectivos cidadãos acerca das viagens ao Brasil durante os jogos olímpicos. Debate-se, inclusive, a possibilidade da suspensão da organização no Brasil. Tais fatos enquadram-se nas estratégias defensivas (Joffe; Haarhoff, 2002; Ungar, 2001) acionadas diante de climas de incerteza de uma nova doença.

O governo brasileiro, por sua vez, tenta acalmar os ânimos e insegurança, através de declarações e investimentos para combater o vírus durante jogos olímpicos.

"Sob os holofotes das olimpíadas 2016 e para acalmar os estrangeiros, Ricardo Barros se reuniu com os embaixadores de todos os países que contariam com delegações de atletas no Rio" (*****Mat_015 *Rev_CC *Font_*Período_2016 referência da matéria).

A antropóloga e documentarista Debora Diniz, em uma entrevista concedida no programa diálogos Brasil, em setembro de 2016, fala do esquecimento do zika vírus no sertão nordestino, devido ao baixo investimento em regiões interioranas do país, afetando muitas mulheres e, causando em outras o medo e pavor de engravidar.

Ainda segundo Diniz (2016), na mesma entrevista, a cepa brasileira guarda semelhanças com aquela do sul da Ásia, mais concretamente da Polinésia Francesa, contudo neste país é permitido o aborto. A não permissão do aborto no Brasil acaba agravando mais a situação das mulheres brasileiras, nordestinas, pobres e negras, principalmente. A autora afirma: "uma tragédia humanitária. Isso é o que nós estamos vivendo no Brasil”.

Os termos mais significativos da classe 2 - Ministério da Saúde e ações de combate são: governo, ministro, combate, repelentes, água, uso, aborto, público, aedes. As palavras significativamente ausentes são: vírus, zika, estudo. A variável associada a esta classe foi: *Rev_CC (revista Carta Capital).

Os discursos dessa classe abordam questões ligadas às tomadas de posição de autoridades governamentais, com vista a conter a propagação do vírus zika. Abre-se espaço para o debate bioético acerca da disponibilização de produtos farmacológicos, como repelente, acesso ao saneamento básico e questões relacionadas à liberdade de escolha de interrupção do feto nas camadas pobres acometidas pelo zika. Acreditamos que as medidas bioéticas devem ser pensadas, por se tratar de uma doença desigual e que acomete mulheres pobres, em sua maioria negras e nordestinas. Essas mesmas mulheres não têm acesso aos métodos contraceptivos via Sistema único de Saúde (SUS), porém, ouvem declarações de gestores públicos e profissionais de saúde à imprensa dizendo que elas não deveriam engravidar.

A revista Carta Capital, variável significativamente associada à classe a que referimos, traz um olhar crítico sobre o vírus, chamando a responsabilidade das autoridades governamentais e, problematizando o preconceito e a projeção nos estrangeiros, conforme vimos nas matérias a seguir:

"Vejo muita gente colocando a culpa na copa de 2014 como se o Brasil só tivesse recebido turistas estrangeiros durante esse torneio. É um raciocínio simplista, o grande problema são as condições estruturais para a existência do mosquito" (**** *Mat_005 *Rev_CC *Font_Ex1 *Periodo_2016).

O subcorpus: discurso de autoridade política (nacional e internacional), em termos gerais, traz discursos denunciantes e de alerta das autoridades públicas em torno do zika vírus. Chama também a atenção da população para um engajamento coletivo. Esses discursos denunciam as iniquidades na prestação dos serviços públicos de saúde. Ao mesmo tempo, 
fazem alerta quanto a propagação do vírus e os possíveis danos que possa causar, caso o Estado brasileiro e a população não priorizem elementos dos determinantes sociais para saúde, como por exemplo o saneamento público e a recolha adequada dos lixos. O seguinte trecho da Classe 2 demonstra o modo como este discurso é veiculado

No artigo dengue e chikungunya doenças socioambientais, mostramos que é inegável a responsabilidade individual de cada cidadão em manter as casas limpas e sem possíveis criadouros. Porém é imprescindível que o poder público faça a sua parte por meio de planos diretores que privilegiem a sustentabilidade (*****Mat_001 *Rev_CC *Font_RE *Periodo_2015).

O trecho acima acentua uma ponderação na atribuição de causalidade sobre a epidemia Zika, de modo que, ao discutir comportamentos e estratégias de prevenção e controle ao vírus, a Revista Carta Capital destaca ao mesmo tempo a importância de uma participação da população no cuidado domiciliar e o dever do Estado em implementar políticas públicas para prevenção e controle da proliferação do mosquito vetor. Nesse sentido, identifica-se não só uma busca de engajamento individual dos cidadãos para enfrentar a epidemia, como também lembrar ao Estado seu poder de participação.

O conteúdo do subcorpus: discurso de autoridade política (nacional e internacional), de forma geral e mais especificamente da Classe 2, com discursos típicos da Revista Carta Capital, lança um olhar crítico, em defesa da população desprotegida pelas políticas públicas (mulheres negras, pobres e das regiões do nordeste) e das questões socioambientais. A Carta Capital, parece inscrever os seus conteúdos em defesa de interesses reconhecidos como progressistas. Nesse contexto, a defesa da igualdade de direitos e luta contra quaisquer sistemas de opressão e desigualdades sociais explica o olhar crítico e denunciante deste eixo.

No subcorpus 2: discurso de autoridade científica (origens, causas e consequências), a classe 3 traz, como mais significativas, as palavras: febre, dor, sintoma, manchas, corpo, dengue, Uganda, África, articulação, macaco, mal-estar, coceira, Camaçari. As ausências significativas da classe são: país, estudo, cérebro, mulher. As variáveis associadas foram *Rev_CC (Revista Carta Capital) e *período_2015, modalidade que indica matérias publicadas no ano de 2015.

Os discursos desta classe abordam manifestações sintomáticas do zika e dados epidemiológicos articulados a especulações sobre a origem do vírus "brasileiro". O aspecto significativo desta classe deve-se a ausência do elemento cérebro na discussão sobre zika, num momento em que se faz forte associação do vírus com microcefalia.

A mulher é igualmente a ausência significativa no discurso desta classe. A propósito, Diniz (2016) considera que o debate sobre o zika vírus focaliza no bebé e invisibiliza o corpo feminino na doença. Este mecanismo é comum nos discursos midiáticos, que têm hábito de focalizar em determinados aspectos, silenciando e/ou invisibilizando os outros. Em função de fatores conjunturais, situacionais ou temporais, certos elementos ligados à questão da zika podem fazer objeto de debates públicos mais intensos, enquanto que outros escapam às polêmicas. Em outras palavras, podemos observar um fenômeno de focalização (Moscovici, 1976).

Nesta classe observamos ênfase em matérias preocupadas em delimitar o histórico e a origem do Zika Vírus "brasileiro", presentes tanto em matérias da Carta Capital, quanto da Veja. Destacamos as variações entre os conteúdos de cada veículo. 
A Carta Capital traz um olhar crítico das sociedades modernas, em decorrência de grandes aglomerações e êxodo rural, fruto das desigualdades sociais e regionais do Brasil, conforme aponta o trecho a seguir

\begin{abstract}
Elas são resultado do avanço do homem sobre a natureza assim como do modelo hegemônico de convivência nas sociedades modernas, que gerou os grandes conglomerados urbanos. Repletos de desigualdades que propiciam um novo ciclo entre homem e mosquito transmissor, mantendo a circulação viral dessa arbovirose e a perpetuação dessas doenças $(* * * * *$ Mat_001 *Rev_CC *Font_RE *Periodo_2015).
\end{abstract}

Já a revista Veja se mostrou mais sutil no olhar crítico acerca do domínio do homem sobre a natureza. Conforme vimos no trecho que se segue:

"Com o avanço do homem em regiões selvagens, o mosquito que transmite a dengue passou a picar humanos. Existem quatro tipos de vírus diferentes, todos com os mesmos sintomas e mesma forma de tratamento" (**** *Mat_24 *Rev_Veja *Font_RE *Periodo_2016).

Em ambas as revistas é possível encontrar matérias que associam o Zika vírus com a África, nomeadamente via ligação com o macaco. Esta hipótese, que liga as doenças emergentes, no ocidente de modo geral e no Brasil mais especificamente, à África, foi amplamente discutida nos trabalhos de Oliva (2005), Rodrigues (2012) e Danfá (2016). De acordo com estes autores, esta ligação tem como objetivo culpabilizar os africanos pelos males e doenças mal resolvidos no Brasil, e, por conseguinte, revela o preconceito racial que os brasileiros têm com relação aos africanos e negros. Observem os trechos a seguir.

"Foi identificado em 1947 em macacos da floresta de Zika em Uganda, daí seu nome e provocava apenas infecções esporádicas em humanos com sintomas brandos, como manchas avermelhadas febre baixa e leve mal-estar" (**** *Mat_24 *Rev_Veja *Font_RE *Periodo_2016).

Esses mosquitos emergiram em aldeias do norte da África há milênios, em épocas de seca quando os habitantes precisavam armazenar água. A adaptação ao convívio doméstico possibilitou a transmissão para o homem e mais tarde a disseminação para as américas e Europa pelo tráfico de escravos (**** *Mat_003 *Rev_CC *Font_RE *Periodo_2016).

A classe 4 - Consequências do Zika - apresenta as seguintes palavras como mais significativas: estudo, bebê, cérebro, célula, infecção, estrutura, vírus, cerebral, anticorpo, publicar, descobrir, feto, células-tronco. As palavras significativamente ausentes são: mosquito, país, OMS. As variáveis associadas a esta classe foram: *Rev_VE (Revista Veja); *Período_2016. Os discursos dessa classe abordaram as possíveis consequências que o vírus zika possa provocar no futuro, utilizando indiretamente a voz dos cientistas investidos de poder para falar sobre o vírus.

Embora não comprovada, os especialistas levantam hipóteses causais em torno da associação do vírus zika com microcefalia nos bebês e possíveis danos cerebrais que o vírus possa acarretar nos adultos. Na busca das causas e consequências que o vírus provoca, os especialistas (nacionais e internacionais) e OMS decretaram estado de emergência mesmo com a incerteza sobre a origem e formas de contágio do zika. Tal posicionamento dos especialistas mobilizou a mídia, que começou a levantar espectro em torno do vírus, causando pânico e terror nas pessoas, principalmente nas grávidas. Estes últimos pela associação com microcefalia e danos neurológicos que zika é capaz de causar provocou nelas um clima medo, ansiedade e angústia. É este clima de incerteza, medo do desconhecido e estupor que oferece um terreno fértil para construção de representações sociais (Moscovici, 2012). Elas surgem 
para dar conta da dificuldade e desconforto humano de suportar um clima de incerteza, tal como o construído em torno da epidemia Zika.

O subcorpus 2 traz o debate científico acerca do vírus zika, na busca de explicações, consequências e possíveis repercussões desta epidemia. Mesmo em um momento carente de explicações seguras e consistentes, os conteúdos acerca desse fenômeno ganham o cotidiano social e mantêm-se fortes na comunicação social durante o período pesquisado. O próprio clima de insegurança e reticências sobre os desdobramentos futuros ativa um movimento social de se informar e produzir informações sobre o Zika Vírus. Essa procura pela explicação é o meio capaz de acalmar os ânimos diante do medo do desconhecido. O subcorpus aborda igualmente o modo como as doenças são encaradas no Brasil, ora desmascarando as desigualdades sociais, ora ligando a doença ao exogrupo, de modo a criar a sensação de que o Brasil é um país salubre.

\section{Análise de correspondência}

Apresentaremos a seguir a análise de correspondência também gerada pelo Iramuteq, após a CHD. A projeção dos dados em um plano fatorial favorece a percepção dos distanciamentos e aproximações dos mundos lexicais apresentados em cada classe da CHD. $\mathrm{Na}$ projeção mostrada na Figura 2 podemos perceber os termos mais significativos (em evidência por tamanho da fonte), as modalidades de variáveis com maior associação para cada eixo e a interpretação das oposições observadas na nomeação dos polos de cada fator, realizada pelos pesquisadores.

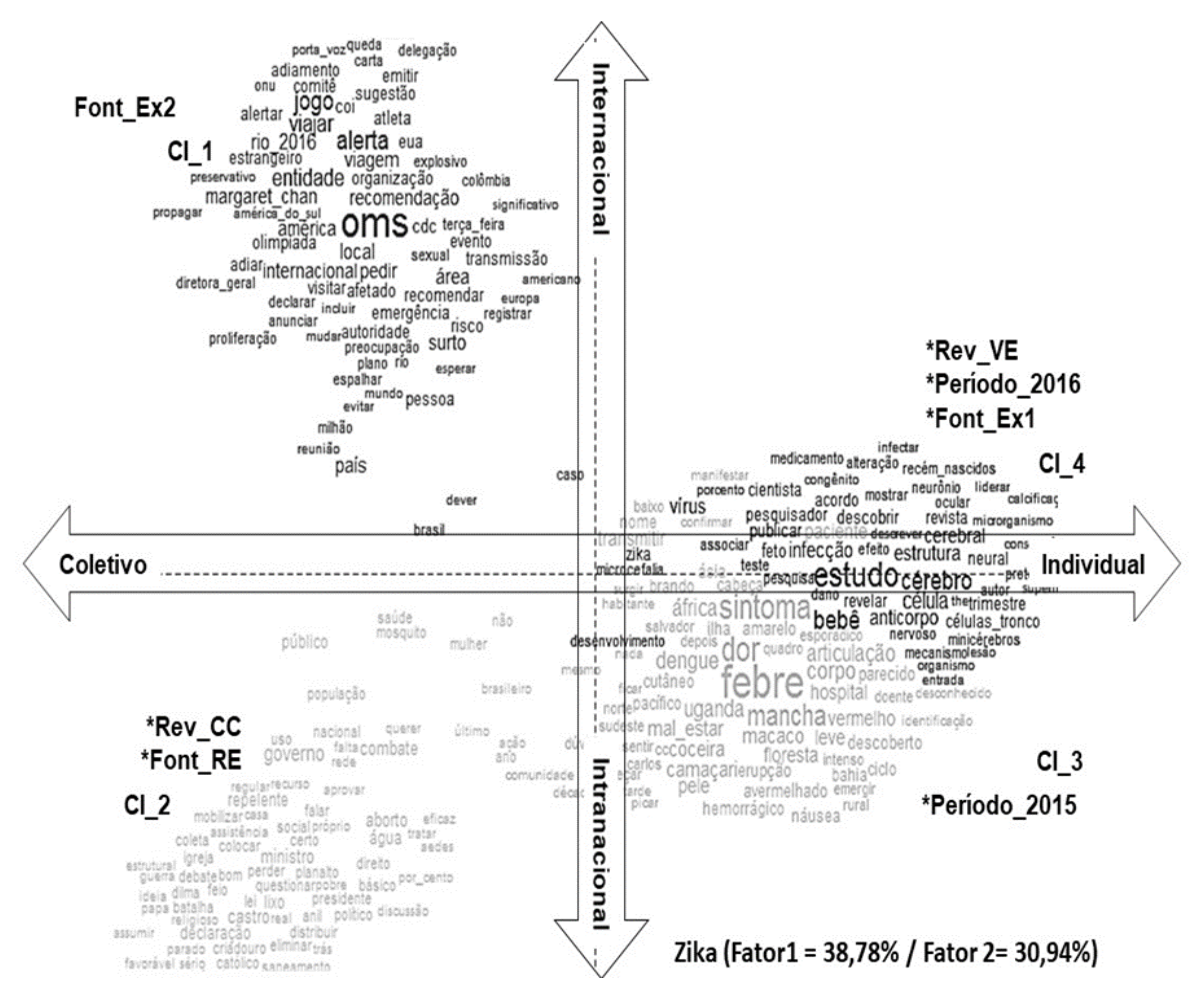

Figura 2 - Análise Fatorial de Correspondência

O primeiro fator (horizontal) da análise de correspondência nos indica uma oposição entre os conteúdos das classes 1 e 2 versus classes 3 e 4 . Essa oposição marca uma polarização 
entre conteúdos com foco no indivíduo, ligados ao discurso da autoridade científica e conteúdos com foco na coletividade, ligados a discursos de autoridade política sobre o Zika Vírus.

Essa oposição entre indivíduo e coletividade fica bastante evidente ao observarmos os termos mais significativos em cada polo. Tais como, febre, cerebro, dor, sintoma, bebê, termos associados ao polo positivo do fator horizontal, que nomeamos de polo de conteúdos focados no indivíduo. Aqui o indivíduo, seus comportamentos e seus sintomas, são o centro das preocupações vinculadas ao Zika. No polo negativo desse fator observamos: jogos, OMS, alerta, governo, combate. Estão presentes conteúdos preocupados com ações e repercussões coletivas sobre os efeitos do Zika.

A modalidade Revista Carta Capital encontra-se mais associada ao polo composto por preocupações coletivistas, do que ao polo do indivíduo. Por outro lado, a modalidade Revista Veja encontra-se associada ao polo do indivíduo. Ambas revistas possuem conteúdos de difusão sobre o novo fenômeno, entretanto o foco (indivíduo ou coletividade) das publicações demonstra uma variação no que consideramos como objeto da preocupação sobre os efeitos do vírus.

O segundo fator (vertical) retido na análise de correspondência apresenta uma fraca contribuição para as classes 3 e 4, de modo que podemos observar estes conteúdos muito próximos da origem (zero). Já para as classes 1 e 2 é perceptível uma forte oposição em função do eixo vertical. Tal oposição destaca, no polo internacional, com associação da modalidade Revista Veja, conteúdos sobre as consequências do Zika para os jogos olímpicos, preocupações de organizações internacionais sobre origens históricas, medidas de contenção para que o vírus não circule entre outros países.

Percebemos, aqui, uma dimensão macrossocial do fenômeno Zika Vírus, uma vez que a descoberta do vírus e a epidemia gerada por ele ativou a participação e preocupação de órgãos nacionais e internacionais nas pesquisas e busca por "controle" da epidemia. Os limites da comunicação social, no que diz respeito ao Zika Vírus ultrapassou barreiras nacionais, engajou a participação de vários países nas estratégias de saúde para conter a epidemia. A realização dos jogos olímpicos e a ameaça decorrente da grande circulação de pessoas de várias nacionalidades no estado do Rio de Janeiro podem ter contribuído para o engajamento das mídias internacionais sobre o fenômeno Zika.

Já no polo negativo, nomeado intranacional, com associação da modalidade Revista Carta Capital, os conteúdos são também de ordem coletiva, entretanto não extrapolam os limites nacionais. Percebem-se especificidades de conteúdos ligados a uma dimensão privada e/ou intrapessoal, com preocupações sobre políticas públicas nacionais de combate ao vetor da doença, cuidados com o lixo doméstico e com saneamento básico.

\section{Considerações finais}

A emergência do zika mobilizou atores sociais, gestores públicos de saúde nacional, e também internacional. A ascensão do debate em torno da epidemia acirrou um clima de clivagens e de diferenciação social entre regiões brasileiras, como o nordeste versus o sul e sudeste, por exemplo. Este contexto ativa jogos de categorização social e proteções identitárias, comuns quando nos deparamos fenômenos dessa natureza. 
As matérias das duas revistas apresentaram proximidades e especificidades nos elementos discursivos. Aproximações no que se refere a difusão de dados epidemiológicos, projeções catastróficas sobre o vírus e cobertura das variações nas hipóteses científicas relatadas pelos especialistas. Distanciamentos em função da cobertura sobre os conteúdos bioéticos ou ênfase no sujeito racionalizante e produtor do seu contexto.

A variação entre os conteúdos veiculados entre as duas revistas tornou-se ainda mais explícita a partir da análise de correspondência, que realçou a oposição entre uma preocupação microssocial nos destaques da Revista veja, versus uma preocupação macrossocial da Carta Capital. Desse modo, enquanto a revista Carta Capital se preocupou com efeitos nefastos da zika no país e as causas vinculadas à falta de saneamento básico e políticas públicas voltadas à melhoria na qualidade de vida socio-habitacional dos brasileiros, a revista Veja destacou preocupações macropolíticas nas relações internacionais vinculadas ao evento de jogos olímpicos no Brasil e realça as dimensões privadas e biomédicas da doença.

\section{Referências}

Aguiar, R. \&, Araujo, I. S. (2016). A mídia em meio às "emergências" do vírus Zika: questões para o campo da comunicação e saúde.

Beck, U. (2010). A política na sociedade de risco. Revista Idéias, 2(1), 230-252.

Bateman-Novaes. S. (1997). De la thérapeutique comme norme. La pensée, (312), 21-32.

Bateman-Novaes, S. (1998). La bioéthique comme objet sociologique. Cahiers internationaux de sociologie, 5-32.

Camargo, B. V., \& Justo, A. M. (2013). Tutorial para uso do software de análise textual IRAMUTEQ. Universidade Federal de Santa Catarina. Recuperado em 18 agosto de 2015 de http://www.iramuteq.org/documentation/fichiers/tutoriel-en-portugais.

Danfá, L. (2016). Alteridade, racismo e representações sociais: o caso do ebola no Brasil. Dissertação de Mestrado, Universidade Federal de Pernambuco. Recife, PE, Brasil.

Diniz, D., Bellezi Guilhem, D., \& Garrafa, V. (1999). Bioethics in Brazil. Bioethics, 13(3-4), 244-248.

Diniz, D., Guilhem, D. (2002). O que é bioética. São Paulo: editora Brasiliense.

Diniz, D. (2008). Bioética e gênero. Revista Bioética, 16(2), 207-216.

Diniz, D., Brito, L. (2016). Epidemia provocada pelo vírus Zika: informação e conhecimento. Recuperado em 16 de setembro de 2016 de http://www.arca.fiocruz.br/handle/icict/16968.

Diniz, D. (2016). Zika mais que um problema de saúde. Entrevista. Dialogo Brasil. TVBRASIL. Recuperado em 14 de setembro de 2016 de http://tvbrasil.ebc.com.br/dialogobrasil/episodio/zika-mais-que-um-problemade-saude.

Galloux, J. C., Mortensen, A. T., De Cheveigne, S., Allansdottir, A., Chatjouli, A., \& Sakellaris, G. (2002). The institutions of bioethics: a comparison of Denmark, France, Italy and Greece. In M. W. Bauer \& G. Gaskell (Orgs.), Biotechnology: The making of a global controversy (pp. 129-148). Cambridge; New York; London: Cambridge University Press.

Herzlich, C, \& Pierret, J. (2005). Uma doença no espaço público: a AIDS em seis jornais franceses. Physis: Revista de Saúde Coletiva, 15(Supl.), 71-101.

Herzlich, C., \& Pierret, J. (1988). Une maladie dans l'espace public. Le sida dans six quotidiens français. In Annales. Histoire, Sciences Sociales (Vol. 43, no. 5, pp. 1109-1134). Cambridge : University Press.

Joffe, H. (2005). De la perception à la représentation du risque: le rôle des médias. Hermès, La Revue, (1), 121129. 
Joffe, H., \& Haarhoff, G. (2002). Representations of far-flung illnesses: the case of Ebola in Britain. Social science \& medicine, 54(6), 955-969.

Le Coz, P. (2009). La question des risques potentiels. In D. Lecourt (Org.). La santé face au principe de précaution (pp. 132-156). Paris: Presses universitaires de France.

Markova, I., \& Wilkie, P. (1987). Representations, concepts and social change: The phenomenon of AIDS. Journal for the Theory of Social Behaviour, 17(4), 389-409.

Ministério da saúde (2016). Boletim epidemiológico (on-line). Recuperado em 20 de dezembro de 2016 de http://portalarquivos.saude.gov.br/images/pdf/2016/dezembro/20/2016-033---Dengue-SE49publicacao.pdf.

Moscovici, S., \& Hewstone, M. (2005). De la science au sens commun. In S. Moscovici (Org.). La psycologie sociale (2ème, pp. 545-572). Paris: Presses Universitaires de France.

Moscovici, S. (2011). A invenção da sociedade: sociologia e psicologia. Petrópolis: Vozes.

Moscovici, S. (1961). La psychanalyse, son image et son public. Paris: Presses Universitaires de France.

Moscovici, S. (2012). A Psicanálise, Sua Imagem e Seu Público. Petrópolis: Vozes. (Trabalho original publicado em 1961).

Nascimento, A. R. A. D., \& Menandro, P. R. M. (2006). Análise lexical e análise de conteúdo: uma proposta de utilização conjugada. Estudos e pesquisas em psicologia, 6(2), 72-88.

Oliva, A. R. (2005). Os africanos entre representações: viagens reveladoras, olhares imprecisos e a invenção da África no imaginário Ocidental. Tempo de história (Vol. 9, pp. 90-114). Brasília, DF.

Rodrigues, J. (2012). Reflexões sobre tráfico de africanos, doenças e relações raciais. História e Perspectivas, 25(47), 15-34.

Rose, N. (2013). A política da própria vida. Biomedicina, poder e subjetividade no século XXI. São Paulo: Paulus.

Spink, M. J. P., Medrado, B., Menegon, V. M., Lyra, J., \& Lima, H. (2001). A construção da AIDS-notícia. The making of AIDS news. Cad. Saúde Pública, 17(4), 851-862.

Schramm, F. R. (2002). A pesquisa bioética no Brasil entre o antigo e o novo. Cadernos Adenauer, III(1), 87-101.

Ungar, S. (2001). Moral panic versus the risk society: The implications of the changing sites of social anxiety. The British journal of sociology, 52(2), 271-291. 